\title{
The Activity and Enthalpy of Vaporization of Nicotine from Tobacco at Moderate Temperatures *
}

\author{
by \\ F. Kelley St.Charles ${ }^{1}$ and Serban C. Moldoveanu ${ }^{2}$ \\ ${ }^{1}$ St.Charles Consultancy, 585 Eden Rock Road, Lewisville, NC 27023, USA \\ ${ }^{2}$ R.J. Reynolds Tobacco Co., 950 Reynolds Boulevard, Winston-Salem, NC 27105, USA
}

\section{SUMMARY}

The vapor pressure of nicotine has been reported for unprotonated nicotine and for nicotine-water solutions. Yet no published values exist for nicotine in any commercially relevant matrix or for protonated forms (e.g., tobacco, smoke, electronic cigarette solutions, nicotine replacement products, nicotine salts). Therefore a methodology was developed to measure nicotine activity (defined as the vapor pressure from a matrix divided by the vapor pressure of pure nicotine). The headspace concentration of nicotine was measured for pure nicotine and tobacco stored at 23, 30 , and $40{ }^{\circ} \mathrm{C}$ which allowed for conversion to vapor pressure and nicotine activity and for the estimation of enthalpy of vaporization. Burley, Flue-cured, Oriental, and cigarette blends were tested. Experiments were conducted with pure nicotine initially until the storage and sampling techniques were validated by comparison with previously published values. We found that the nicotine activity from tobacco was less than $1 \%$ with Burley $>$ Flue-cured $>$ Oriental. At $23{ }^{\circ} \mathrm{C}$ the nicotine vapor pressure averaged by tobacco type was $0.45 \mathrm{mPa}$ for Oriental tobacco, $1.8 \mathrm{mPa}$ for Flue-cured, $13 \mathrm{mPa}$ for Burley while pure nicotine was $2.95 \mathrm{~Pa}$. In general, the nicotine activity increased as the (calculated) unprotonated nicotine concentration increased. The nicotine enthalpy of vaporization from tobacco ranged from $77 \mathrm{~kJ} / \mathrm{mol}$ to $92 \mathrm{~kJ} / \mathrm{mol}$ with no obvious trends with regard to tobacco origin, type, stalk position or even the wide range of nicotine activity. The mean value for all tobacco types was $86.7 \mathrm{~kJ} / \mathrm{mol}$ with a relative standard deviation of $6.5 \%$ indicating that this was an intrinsic property of the nicotine form in tobacco rather than the specific tobacco properties. This value was about $30 \mathrm{~kJ} / \mathrm{mol}$ greater than that of pure nicotine and is similar to the energy needed to remove a proton from monoprotonated nicotine. [Beitr. Tabakforsch. Int. 27 (2016) 11-19]

\section{ZUSAMMENFASSUNG}

Der Dampfdruck von Nikotin wurde bereits für nicht protoniertes Nikotin und für Nikotin-Wasser-Lösungen bestimmt. Jedoch gibt es in der Literatur keine Werte für Nikotin in einer kommerziell relevanten Matrix oder für protonierte Formen (z.B. Tabak, Rauch, elektronische Zigarettenlösungen, Nikotinersatzprodukte, Nikotinsalze). Deshalb wurde ein Verfahren zur Messung der Nikotinaktivität entwickelt (definiert als der Dampfdruck einer Matrix geteilt durch den Dampfdruck von reinem Nikotin). Die Headspace-Konzentration von Nikotin wurde für reines Nikotin und Tabak bei einer Lagerung bei 23,30 und $40{ }^{\circ} \mathrm{C}$ gemessen und ermöglichte die Umrechnung in Dampfdruck und Nikotinaktivität sowie die Schätzung der Enthalpie der Verdampfung. Es wurden Burley, Flue-cured und Orienttabak sowie Tabakmischungen für Zigaretten getestet. Zunächst wurden Experimente mit reinem Nikotin durchgeführt, bis die Lagerungs- und Probenahmeverfahren durch Vergleich mit den zuvor veröffentlichten Werten validiert wurden. Es wurde festgestellt, dass die Nikotinaktivität von Tabak unter $1 \%$ lag, und zwar Burley $>$ Flue-cured $>$ 
Orienttabak. Bei $23{ }^{\circ} \mathrm{C}$ betrug der Nikotindampfdruck im Mittel je nach Tabaksorte $0,45 \mathrm{mPa}$ für Orienttabak, 1,8 $\mathrm{mPa}$ für Flue-cured, $13 \mathrm{mPa}$ für Burley und im Vergleich dazu 2,95 Pa für reines Nikotin. Die Nikotinaktivität stieg im Allgemeinen mit der Zunahme der (berechneten) Konzentration des nicht protonierten Nikotins. Die Nikotinenthalpie der Verdampfung von Tabak lag zwischen $77 \mathrm{~kJ} / \mathrm{mol}$ und $92 \mathrm{~kJ} / \mathrm{mol}$ ohne erkennbare Trends hinsichtlich Tabakherkunft, Sorte, Stengelposition oder auch der breiten Palette der Nikotinaktivität. Der Mittelwert für alle Tabaksorten betrug $86,7 \mathrm{~kJ} / \mathrm{mol}$ mit einer relativen Standardabweichung von $6,5 \%$, die anzeigte, dass es sich hierbei eher um eine intrinsische Eigenschaft der Nikotinform im Tabak handelte und nicht um spezifische Eigenschaften eines bestimmten Tabaks. Dieser Wert lag etwa $30 \mathrm{~kJ} / \mathrm{mol}$ über dem von reinem Nikotin und entspricht ungefähr der Energie, die notwendig ist, um aus monoprotoniertem Nikotin ein Proton zu entfernen. [Beitr. Tabakforsch. Int. 27 (2016) 11-19]

\section{RESUME}

La pression de vapeur de la nicotine est documentée pour la nicotine non protonée ainsi que pour les solutions nicotine-eau. Cependant, aucune valeur n'a été publiée pour la nicotine contenue dans les matrices disponibles dans le commerce ou pour ses formes protonées (par exemple, le tabac, la fumée, les solutions pour les cigarettes électroniques, les produits de substitution de la nicotine et les sels de nicotine). Par conséquent, une méthodologie a été mise au point afin de mesurer l'activité nicotinique (définie comme la division de la pression de vapeur d'une matrice par la pression de vapeur de la nicotine pure). La concentration de la nicotine dans l'espace de tête a été mesurée pour la nicotine pure et le tabac entreposé à des températures de 23,30 et $40^{\circ} \mathrm{C}$, qui suscitent la conversion en pression de vapeur et l'activité nicotinique et permettent l'estimation de l'enthalpie de la vapeur. Le tabac burley, le tabac jaune, le tabac d'orient et des mélanges pour cigarettes ont été testés. Les expériences ont été menées initialement avec de la nicotine pure jusqu'à ce que les techniques d'entreposage et d'échantillonnage soient validées par comparaison avec les valeurs précédemment publiées. Nous avons observé que l'activité nicotinique du tabac était inférieure à $1 \%$ dans le cas du tabac burley $>$ du tabac jaune $>$ du tabac d'orient. A une température de $23^{\circ} \mathrm{C}$, la pression de vapeur de la nicotine mesurée en moyenne par type de tabac s'élève à $0,45 \mathrm{mPa}$ pour le tabac d'orient, $1,8 \mathrm{mPa}$ pour le tabac jaune, $13 \mathrm{mPa}$ pour le tabac burley tandis que cette mesure pour la nicotine pure atteint $2,95 \mathrm{mPa}$. En règle générale, l'activité nicotinique s'intensifie lorsque la concentration en nicotine non protonée (calculée) augmente. L'enthalpie de vaporisation de la nicotine contenue dans le tabac oscille entre $77 \mathrm{~kJ} / \mathrm{mol}$ et $92 \mathrm{~kJ} / \mathrm{mol}$ alors qu'aucune tendance évidente n'est observée concernant l'origine ou le type de tabac, la position de la tige ou même la large plage d'activité nicotinique. La valeur médiane pour tous les types de tabac s'élève à $86,7 \mathrm{~kJ} / \mathrm{mol}$ pour un écart-type relatif de $6,5 \%$ et révèle qu'il s'agit d'une propriété intrinsèque de la forme de nicotine contenue dans le tabac et non de propriétés associées à un tabac spécifique. Cette valeur est approximativement de $30 \mathrm{~kJ} / \mathrm{mol}$ supérieure à celle de la nicotine pure et est similaire à l'énergie nécessaire pour enlever un proton à la nicotine mono-protonée. [Beitr. Tabakforsch. Int. 27 (2016) 11-19]

\section{KEYWORDS}

Vapor pressure, enthalpy of vaporization, headspace, nicotine, activity, Burley, Flue-cured, Oriental, 3R4F Kentucky Reference Cigarette

\section{INTRODUCTION}

In previous work (1) on the migration of propylene glycol, glycerin and nicotine from cigarette tobacco to the filter, it was inferred that the vapor pressure of nicotine in tobacco was closer to that of glycerin than propylene glycol. However pure nicotine has a vapor pressure much closer to that of propylene glycol than that of glycerin. At $25^{\circ} \mathrm{C}$, the vapor pressure of pure nicotine has been reported to range from 2.6 to $5.7 \mathrm{~Pa}$ depending on the reference (2-6), while the vapor pressures for propylene glycol and glycerin are reported as $17 \mathrm{~Pa}(7)$ and $0.022 \mathrm{~Pa}(8)$, respectively. It was not surprising that nicotine vapor pressure from tobacco would be much lower than pure nicotine since the $\mathrm{pH}$ of tobacco extract slurries indicates that nicotine in tobacco would primarily be protonated and exist in salt form. We searched the literature for any data on the vapor pressure of nicotine from tobacco. Although quantitative data were found for pure nicotine and nicotine/water solutions (2-6), as well as qualitative data for nicotine in tobacco headspace (9-11), no quantitative data were found for nicotine vapor pressure from tobacco. Therefore, we decided to attempt the quantitative measurement of the amount of nicotine in tobacco headspace. Since no data existed for evaluating the technique, the headspace of pure nicotine was also measured for comparison with previous determinations. In addition, measuring the vapor pressure of nicotine from both pure nicotine and tobacco using the same technique allows a more accurate determination of nicotine activity from tobacco. Nicotine activity in any matrix is defined as the vapor pressure of nicotine from the matrix divided by the vapor pressure of pure nicotine at the same temperature. Therefore, any systematic error due to experimental technique would apply to both the numerator and denominator and be cancelled. Because of the anticipated difference in vapor pressure, we roughly estimated that the gas volume needed for a sample would be on the order of milliliters for pure nicotine and liters for tobacco headspace to get a measurable amount. This meant using either an equilibrated headspace technique with sampling from flexible containers or a gas-saturation flow technique (12). Since the rate at which nicotine would transfer from tobacco to gas was unknown, we decided on headspace sampling from flexible containers. This would allow equilibration times on the order of days and weeks rather than minutes using the gas-saturation flow technique. The use of flexible containers also avoids the need for a vacuum system with fixed volumes and separately heated regions such as described by CHICKOS (13). 


\section{EXPERIMENTAL}

Experiments were conducted with pure nicotine initially until the storage and sampling techniques were validated by comparison with previously published values. We tested methods of sampling headspace and flexible containers until the values we achieved for vapor pressure were comparable to the published values. Notice the $-50 \% /+100 \%$ range in reported vapor pressure at $25{ }^{\circ} \mathrm{C}$ mentioned above. This sort of variation could occur if temperature varied $\pm 3{ }^{\circ} \mathrm{C}(4,5)$ or if $10 \%$ water $(50 \mathrm{~mol} \%)$ were absorbed into nicotine (3). Headspace concentration of nicotine was measured at 23,30 , and $40{ }^{\circ} \mathrm{C}$.

\section{Reagents}

- L-Nicotine (Highly poisonous. Use care and appropriate personal protection equipment when handling.) Acros Organics 98\% (Thermo Fisher Scientific, Waltham, MA, USA) and Siegfried (Pennsville, NJ, USA) 99.8\%.

- Internal standard (I.S.) - (+/-) deuterated nicotine (methyl-d3) (Toronto Research Chemicals, Toronto, Canada).

- Extraction solution - Ethyl acetate 99.9\% with 5000 ppm triethylamine 99.5\% (both from SigmaAldrich, St.Louis, MO, USA)

\section{Headspace sampling and extraction}

XAD-4 Sampling - The method of concentrating the nicotine from tobacco headspace starting with multi-liter samples of gas to $\mathrm{mL}$ volumes of solvent for analysis was to use $6 \mathrm{~mm}$ diameter $\times 70 \mathrm{~mm}$ long sorbent sampling tubes containing $120 \mathrm{mg}$ of XAD-4 resin (Cat. No. 226-170, SKC Inc. Eighty Four, PA, USA). These sorbent tubes, along with sampling, extraction and analysis methods have been previously validated for the analysis of nicotine in environmental tobacco smoke (14-17). The general configuration of the XAD-4 cartridges for sampling is shown in Figure 1. The needle was used to sample through a septum on the gas bags. The other end of the needle was inserted into the sorbent tube opening. This minimized dead volume and surface for adsorption of nicotine. This also eliminated any contact of the vapor with rubber or plastic which has been shown to significantly absorb nicotine $(2,3,18)$. After sampling, the tubes were capped, placed in capped glass vials and stored at $-20^{\circ} \mathrm{C}$ until sorbent extraction.

Suction was applied to the tubing on the end of the sorbent tube opposite from the needle. For nicotine headspace, a $10 \mathrm{~mL}$ GASTIGHT ${ }^{\circledR}$ syringe (Model 1010W, Hamilton Co., Reno, NV, USA) with a Luer lock tubing connector was used. For tobacco headspace, suction was applied using a single stage of a 2-stage diaphragm pump (Vacu-

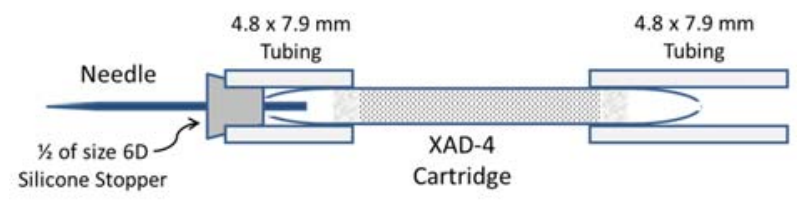

Figure 1. XAD-4 sorbent tube holder. brand GMBH Type MZ 2B, Wertheim, Germany). A diagram of the tobacco headspace sampling system is shown in Figure 2.

Nylon tubing connected the XAD-4 tube holder to a needle valve attached to the suction side of the diaphragm pump. The needle valve was used to regulate flow while maintaining near atmospheric pressure on the XAD-4 tube. A rotometer was attached with nylon tubing on the exhaust side of the diaphragm pump to assure a flow rate of about $250 \mathrm{~mL} / \mathrm{min}$. The gas then passed into copper tubing coiled inside a $4 \mathrm{~L}$ beaker containing about $1.5 \mathrm{~L}$ of water. All tubing was $1 / 4$ " $(6.35 \mathrm{~mm})$ outside diameter. Volume was checked by bubbling the gas into an inverted $2 \mathrm{~L}$ volumetric flask which had been calibrated in $5 \mathrm{~mL}$ increments from $1980 \mathrm{~mL}$ to $2020 \mathrm{~mL}$. Prior to sampling, the volumetric flask was filled with water, capped with a ground glass stopper, inverted until the cap was below water level in the beaker and the stopper removed. After collecting approximately $2 \mathrm{~L}$ of gas the pump was turned off. The volume was estimated to the nearest $\mathrm{mL}$ by raising the flask until the water level inside the flask was slightly above the level outside the flask to determine a meniscus. The temperature of the water in the beaker and the air surrounding the gas bag was measured with a type $\mathrm{K}$ thermocouple. This assured a known temperature and volume of gas sampled regardless of the storage temperature of the gas bag. The volume was then corrected to the measured temperature in which the gas bag was stored. The sorbent tubes were located inside the environmental chambers when sampling which prevented water condensation for samples at higher temperatures. For some of the initial samples of tobacco headspace at room temperature, a $1500 \mathrm{~mL}$ gas sampling syringe (Model S-1500, Hamilton Co., Reno NV) with a Luer lock tubing connector was used.

In-syringe sampling - For pure nicotine headspace, an additional method was used besides the XAD-4 cartridge. With this method, extraction solution was pulled into a $10 \mathrm{~mL}$ GASTIGHT ${ }^{\circledR}$ syringe which had a needle and shutoff valve (Model 1010, Hamilton Co., Reno, NV, USA). The plunger was depressed until all air was expelled and $1.5 \mathrm{~mL}$ of solvent remained in the syringe. The shutoff valve was then closed. The needle was then inserted through the septum of a gas bag, the valve opened, and headspace was slowly bubbled through the solution until the desired gas volume was obtained. The shutoff valve was closed and the syringe was shaken for $5 \mathrm{~min}$. The solution was then added to $1.5 \mathrm{~mL}$ screw cap glass vial and capped with a polytetrafluoroethylene (PTFE) lined septa (Agilent

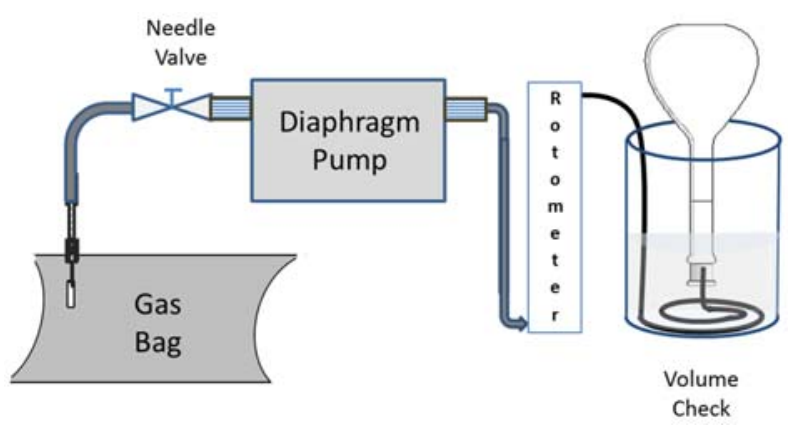

Figure 2. Schematic of the tobacco headspace sampling 
Table 1. Conditions for the GC/MS/MS analysis of nicotine.

\begin{tabular}{|c|c|}
\hline Parameter & Description \\
\hline Initial oven temperature & $50{ }^{\circ} \mathrm{C}$ \\
\hline Initial time & $1.0 \mathrm{~min}$ \\
\hline Oven ramp rate & $10^{\circ} \mathrm{C} / \mathrm{min}$ \\
\hline Oven temperature 1 & $240^{\circ} \mathrm{C}$ \\
\hline Final time & $10 \mathrm{~min}$ \\
\hline Total run time & $30.0 \mathrm{~min}$ \\
\hline Inlet temperature & $280^{\circ} \mathrm{C}$ \\
\hline Inlet mode & pulsed split \\
\hline Purge time & $0.5 \mathrm{~min}$ \\
\hline Pulse pressure & 25 psi \\
\hline Pulse time & $1 \mathrm{~min}$ \\
\hline Purge flow to split vent & $30.0 \mathrm{~mL} / \mathrm{min}$ \\
\hline Carrier gas & helium \\
\hline Injection volume & $1.0 \mathrm{~mL}$ \\
\hline Flow mode & constant flow \\
\hline Flow rate & $1.0 \mathrm{~mL} / \mathrm{min}$ \\
\hline Nominal initial pressure & 7.65 psi \\
\hline Average velocity & $36.44 \mathrm{~cm} / \mathrm{sec}$ \\
\hline GC outlet & MS/MS \\
\hline Auxiliary temperature & $250^{\circ} \mathrm{C}$ \\
\hline Solvent delay & $4.0 \mathrm{~min}$ \\
\hline Gain factor & 10 \\
\hline MS source temperature & $230^{\circ} \mathrm{C}$ \\
\hline Acquisition mode & MRM \\
\hline d3-Nicotine precursor ion & 165.1 \\
\hline d3 Nicotine product ion & 87.1 \\
\hline MS1 resolution & Unit \\
\hline Dwell time & $120 \mathrm{~ms}$ \\
\hline CE & $11 \mathrm{~V}$ \\
\hline Nicotine precursor ion & 162.1 \\
\hline Nicotine product ion & 84.1 \\
\hline MS1 resolution & Unit \\
\hline Dwell time & $120 \mathrm{~ms}$ \\
\hline CE & $11 \mathrm{~V}$ \\
\hline
\end{tabular}

5182-0715 \& 5182-0717, Santa Clara, CA, USA). Vials were placed in a zipper lock plastic bag and stored at $-20{ }^{\circ} \mathrm{C}$ until analysis. Internal standard was added just prior to analysis. Since the headspace nicotine was directly transferred to extraction solution, this allowed the nicotine recovery from the XAD-4 cartridges to be determined.

Extraction - The XAD-4 resin was extracted by breaking or cutting off the ends of the tubes and emptying the glass wool and resin into $4 \mathrm{~mL}$ glass vials. The inlet end of the tube was also added to the vial. Then $1.5 \mathrm{~mL}$ extracting solution and deuterated nicotine internal standard were added (I.S concentration in the extracting solution was $153 \mathrm{ng} / \mathrm{mL}$ ). Vials were capped and shaken on a wrist action shaker for $30 \mathrm{~min}$. After extraction, the solution was pipetted into the same $1.5 \mathrm{~mL}$ screw cap glass vials and caps as mentioned above. The extraction solution was ethyl acetate containing 5000 ppm of triethylamine (TEA). The TEA was added to prevent adsorption of nicotine onto glass (19).

\section{Headspace nicotine analysis}

The analysis was performed using a GC/MS/MS on a 7890B/7000C system from Agilent (Santa Clara, CA, USA), in multiple reaction monitoring (MRM) mode. The conditions of analysis are described in Table 1. The column used for the separation was a DB-Waxetr $30 \mathrm{~m} \times 0.25 \mathrm{~mm}$ i.d. with a film of $0.25 \mu \mathrm{m}$ thick from Agilent $(\mathrm{J} \& \mathrm{~W})$. This type of column has a high polarity polyethylene glycol (PEG) stationary phase and it is commonly used for nicotine analysis. Nicotine elutes at $14.22 \mathrm{~min}$ (and d3nicotine elutes at $14.19 \mathrm{~min}$ ).

The quantitation for nicotine levels was performed using calibrations of amount of nicotine $v s$. (peak area nicotine)/(peak area I.S). The peak areas for nicotine and that for I.S. d3-nicotine were generated using MRM mode and the quantitation capability of the instrument (MassHunter workstation software). Calibration range was between $4.19 \mathrm{ng} / \mathrm{mL}$ and $2145 \mathrm{ng} / \mathrm{mL}$ and was performed with 10 standards $(4.19,8.38,16.76,33.52, \ldots 2145)$. The equation of the calibration curve was linear,

$$
\mathrm{Y}=129.2 \times \mathrm{X}-0.3021 \text { and had } \mathrm{R}^{2}=0.9995 \text {, }
$$

where $\mathrm{Y}$ is the concentration of nicotine in $\mathrm{ng} / \mathrm{mL}$ and $\mathrm{X}$ is (peak area nicotine)/(peak area I.S.). The signal to noise ratio was 240 for a standard solution with the concentration of $8.38 \mathrm{ng} / \mathrm{mL}$. This ratio indicates the excellent sensitivity of the procedure.

\section{Flexible gas bags}

In initial feasibility trials, we confirmed that plastic bags were unsuitable. Nicotine in a polyethylene (PE) zipper lock bag at room temperature gave a vapor concentration of about $10 \%$ of the published values. We decided to line multi-layer foil gas bags with a liner made of heavy-duty aluminum foil $(\sim 23.5 \mu \mathrm{m}$ thickness; Reynolds Consumer Products, Lake Forest, IL, USA). The aluminum foil liners were too fragile to use without a protective covering and the multi-layer foil gas bags have a polyethylene heat seal layer on the inside so the two were combined.

First set of experiments - For the first set of room temperature measurements we used Restek (State College, PA, USA) multi-layer gas sample bags with a polypropylene combo valve and replaceable septum. One liter bags (catalog \#22950) were used for pure nicotine and $10 \mathrm{~L}$ bags (catalog \# 22953) were used for tobacco. Foil liners were made by folding a double-length sheet of aluminum foil in half. The width was cut to about $3 \mathrm{~cm}$ greater than the liner width desired. These edges were double folded using about $1 \mathrm{~cm}$ folds. Then the edges and bottom were taped using aluminum foil tape (Nashua 2" $(5 \mathrm{~cm})$ width, Franklin, KY, USA) to prevent pinholes and tearing on the creases. The valve was removed from the gas bags and the aluminum liner slid in. A hole was cut in the liner corresponding to the hole in the gas bag for valve placement and the valve was re-attached using a press fit. After samples (nicotine or tobacco) were placed in the aluminum liner, the liner was folded at the top and aluminum tape applied. The bags were then filled with nitrogen and stored in a temperature controlled environmental chamber. The bags were stored at least a week before sampling. We determined by experimentation that nicotine concentration was lower when sampling through the open valve rather than sampling through the septum. We attributed this to headspace flowing through a path in the polypropylene valve that had 
Table 2. Tobacco types tested

\begin{tabular}{l|c|c|c|c|c|c|c}
\hline Code & Tobacco type & Stalk position & Crop year & Origin & Nicotine (DWB) & Oven volatiles & $\mathrm{pH}$ \\
\hline $\mathrm{BY}_{\mathrm{L}}$ & Burley & low - mid & 2012 & $\mathrm{KY}, \mathrm{USA}$ & $3.08 \%$ & $11.0 \%$ & 6.2 \\
$\mathrm{BY}_{\mathrm{U}}$ & Burley & mid - upper & 2012 & $\mathrm{KY}, \mathrm{USA}$ & $4.74 \%$ & $11.3 \%$ & 5.9 \\
$\mathrm{FC} \mathrm{L}$ & Flue-cured & low - mid & 2012 & Brazil & $2.52 \%$ & $12.6 \%$ & 5.2 \\
$\mathrm{FC}_{\mathrm{U}}$ & Flue-cured & mid - upper & 2012 & Brazil & $3.81 \%$ & $12.2 \%$ & 5.0 \\
$\mathrm{OR}_{\mathrm{U}}$ & Oriental & upper & 2011 & Izmir, Turkey & $0.80 \%$ & $11.2 \%$ & 5.2 \\
$\mathrm{OR}_{\mathrm{M}}$ & Oriental & mid & 2011 & Izmir, Turkey & $0.75 \%$ & $11.9 \%$ & 5.3 \\
$\mathrm{OR}_{\mathrm{L}}$ & Oriental & low & 2011 & Izmir, Turkey & $0.54 \%$ & $10.9 \%$ & 5.5 \\
$3 \mathrm{R}_{\mathrm{F}}$ & Blend & cigarette & -- & KY reference & $2.05 \%$ & $12.7 \%$ & 5.5 \\
$\mathrm{BL}_{\mathrm{C}}$ & Blend & cigarette & -- & commercial & $1.87 \%$ & $12.5 \%$ & 5.2 \\
\hline
\end{tabular}

been isolated from the headspace during storage. Tedlar ${ }^{\circledR}$ bags (SKC Inc., Eighty Four, PA, USA) with stainless steel valves were also tested with nicotine and these gave headspace concentration about $83 \%$ of the foil lined bags. Second set of experiments - After repeated sampling and refills with nitrogen, we noticed a decline in headspace concentration. Inspection of the used bags revealed tearing of the foil due to flexing at the valve connection. We also noticed multiple pin-holes at creased areas made while inflating and deflating the bags. For this generation we decided to eliminate the polypropylene valve/septum holder. We kept the same type foil liner, but added aluminum tape to the liner to reinforce it at the valve penetration. We replaced the valve with a $1 / 8$ " stainless steel Swagelok ${ }^{\circledR}$ (Monroe, NC, USA) union (SS-200-6) attached to the bag and liner with a bulkhead union nut (SS-202-61) on the inside of the liner. On the outside of the bag, a PTFE lined septum replaced the back ferrule on the union. The union on the inside of the bag was left exposed. Aluminum tape was used to reinforce the foil opposite the union to prevent punctures by the exposed edge. The outer bag was made from Sorbent Systems (Impak Corp., Los Angeles, CA, USA) 5 mil ( $127 \mu \mathrm{m})$, 4-layer foil bags (type PAKVF4C). The layers consisted of $16.5 \mu \mathrm{m}$ polyethylene terephtalate (outer), PE, $8.9 \mu \mathrm{m}$ aluminum foil, metallocene PE (inner heat seal). For nicotine, the outer bags were $1 / 2$ of a $10 " \times 16^{\prime \prime}(25 \times 41 \mathrm{~cm})$ bag (Part \# 10VF4C16) and for tobacco they were $1 / 4$ of a $30^{\prime \prime} \times 40 "(76 \times 102 \mathrm{~cm})$ bag (Part \#30VF4C40). This construction left $\sim 3 \mathrm{~mm}$ diameter of the PTFE lined septum as the only non-metal in contact with the headspace. A sample of thicker foil $(0.002 ", 51 \mu \mathrm{m}$, manufacturer unknown) with a printed heat seal layer was also tested as a liner using nicotine. The heat seal layer was $\sim 10 \%$ of the thickness of the laminated PE layer in the Restek gas bags. The thicker foil was tested with the heat seal layer facing in and facing out. The results with the heat seal layer facing in were less than the results obtained with either a heavy-duty foil liner or the heat seal facing out so they were not used.

\section{Tobacco and nicotine samples}

The tobacco types tested are shown in Table 2 along with the respective nicotine content, oven volatiles and $\mathrm{pH}$. The straight grade tobaccos were cut to a standard width (25 cuts per inch) without casing, flavors or humectants. The cigarette blends were taken from manufactured cigarettes.
Prior to use the tobacco was conditioned to a water activity of 0.61 to 0.62 . Oven volatile results in Table 2 are for the conditioned tobacco. The nicotine results are expressed on a dry weight basis (DWB). The analysis method was similar to the CDC method for smokeless tobacco (20). The $\mathrm{pH}$ results are for 1 part ground tobacco extracted with 20 parts water (w:w) for $30 \mathrm{~min}$. and measured on the tobacco/water slurry. Approximately $50 \mathrm{~g}$ of tobacco was placed in the gas bags for headspace analysis. Bags were filled with nitrogen to prevent nicotine oxidation.

For nicotine samples, approximately $1.5 \mathrm{~g}$ nicotine was added to a $44 \mathrm{~mm}$ Cambridge filter pad mounted in an aluminum holder. The holder was made by cutting a square slightly larger than the pad from an aluminum weighing pan, then folding the corners to hold the pad. All edges of the aluminum were then folded up to form a cup-like holder with irregular edges. The pad and holder were used to keep the liquid nicotine from directly contacting the bag while the irregular edges assured an unblocked vapor transport pathway. Bags were filled with nitrogen to prevent nicotine oxidation.

\section{RESULTS}

\section{Nicotine headspace}

The results for headspace sampling of pure nicotine are shown in Table 3. The in-syringe sampling resulted in higher values than with XAD-4 sampling. The mean results with XAD-4 sampling were $61.9 \%$ of those obtained using in-syringe sampling. This proportion was used to adjust for XAD-4 sampling of the tobacco headspace. Also notice that the relative standard deviation for the in-syringe sampling was lower than that from the XAD-4 sampling. Vapor pressure was calculated from the headspace concentration using the Ideal Gas Law. Figure 3 compares the measured values for in-syringe sampling to published values showing that the foil lined gas bags give comparable results and were determined to be suitable for tobacco headspace measurements.

The in-syringe sampling results were fit to the CLAUSIUSCLAPEYRON equation (ln $\mathrm{P}=-\Delta$ Hvap $/ \mathrm{RT}+\mathrm{C}$ ) using a linear regression of

$\ln$ (vapor pressure) versus $1 /$ temperature $\left(\mathrm{K}^{-1}\right)$. 
Table 3. Nicotine headspace concentration and vapor pressure results.

\begin{tabular}{l|c|c|c|r|r}
\hline Sampling & $\begin{array}{c}\text { Temperature } \\
\left({ }^{\circ} \mathrm{C}\right)\end{array}$ & $\begin{array}{c}\text { HS concentration } \\
(\mathrm{ng} / \mathrm{mL})\end{array}$ & $\begin{array}{c}\text { Vapor pressure } \\
(\mathrm{Pa})\end{array}$ & $\begin{array}{c}\text { Relative standard } \\
\text { deviation }(\%)\end{array}$ & $\begin{array}{c}\text { Number of } \\
\text { Replicates }\end{array}$ \\
\hline In-syringe & 23.0 & 194 & 2.95 & 13.1 & 21 \\
In-syringe & 30.0 & 315 & 4.90 & 9.5 & 5 \\
In syringe & 39.5 & 617 & 9.89 & 4.7 & 7 \\
XAD-4 & 23.0 & 126 & 1.91 & 24.3 & 20 \\
XAD-4 & 30.0 & 162 & 2.52 & 24.7 & 5 \\
XAD-4 & 39.5 & 376 & 6.02 & 13.0 & 7 \\
\hline
\end{tabular}

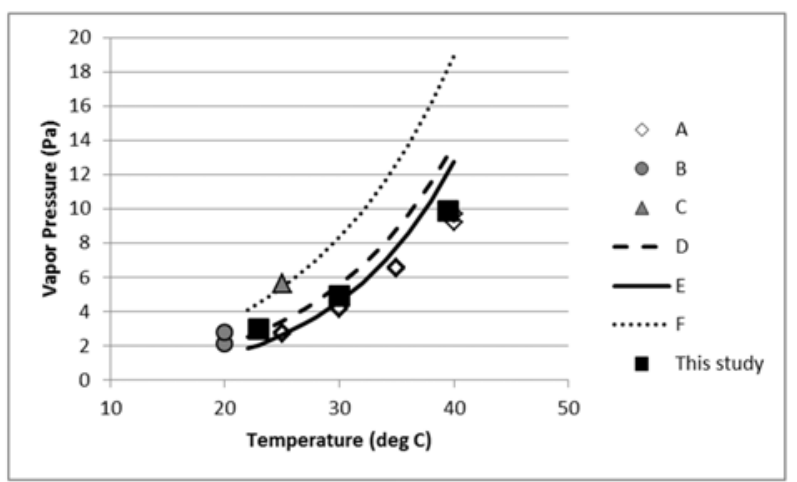

Figure 3. Nicotine vapor pressure (in-syringe extraction) compared to published values. A (Ref. 2), B (Ref. 21), C (Ref. 3), D (Ref. 4, Eqn. 6), E (Ref.5, Eqn.2), F (Ref.22, Eqn. 2)

This gave a slope of $-6807 \mathrm{~K}$ with an $\mathrm{R}^{2}$ value of 0.9995 . The enthalpy of vaporization ( $\Delta$ Hvap) was calculated by multiplying the slope by the negative of the gas constant $(-8.314 \mathrm{~J} / \mathrm{K} / \mathrm{mol})$ (23). The resulting value was $56.6 \mathrm{~kJ} / \mathrm{mol}$. A standard error of $1.2 \mathrm{~kJ} / \mathrm{mol}$ was calculated from the standard error of prediction of the regression. This compares to values of $58.0-82.7 \mathrm{~kJ} / \mathrm{mol}$ using published data or equations for this temperature range $(2,4,5,22)$.

\section{Tobacco headspace}

The results for headspace concentration and vapor pressure of nicotine from the tobacco samples are shown in Table 4. The measured concentration was divided by 0.619 to account for the incomplete recovery from the XAD-4 resin obtained using pure nicotine. The adjusted concentration was used to calculate vapor pressure. The nicotine activity was calculated by dividing the adjusted concentration from tobacco by the measured concentration of pure nicotine from the in-syringe sampling. The results for nicotine activity are expressed as a percentage of the pure nicotine headspace concentration. The vapor pressures in Table 4 are expressed in $\mathrm{mPa}$ while those for pure nicotine in Table 3 are expressed in $\mathrm{Pa}$.

For all temperatures the nicotine activity for Burley $>$ Fluecured $>$ Oriental grades with Burley about 7 times greater than Flue-cured and Flue-cured about 4.5 greater than Oriental. For the blended tobacco, the nicotine activity was similar to or slightly greater than the Flue-cured activity. The vapor pressure of nicotine from tobacco was much less

Table 4. Adjusted headspace concentration (HS Conc.), vapor pressure (VP) and activity for nicotine from differing tobacco types.

\begin{tabular}{|c|c|c|c|c|c|c|c|c|c|}
\hline & $B Y_{L}$ & $B Y_{U}$ & $\mathrm{FC}_{\mathrm{L}}$ & $\mathrm{FC}_{\mathrm{U}}$ & $\mathrm{OR}_{\mathrm{L}}$ & $\mathrm{OR}_{\mathrm{M}}$ & $\mathrm{OR}_{\mathrm{U}}$ & 3R4F & $\mathrm{BL}_{\mathrm{C}}$ \\
\hline \multicolumn{10}{|c|}{$23^{\circ} \mathrm{C}$} \\
\hline HS Conc. (ng/mL) & 0.796 & 0.949 & 0.106 & 0.136 & 0.033 & 0.026 & 0.030 & 0.229 & 0.085 \\
\hline $\mathrm{VP}(\mathrm{mPa})$ & 12.1 & 14.4 & 1.6 & 2.1 & 0.50 & 0.39 & 0.45 & 3.5 & 1.3 \\
\hline $\operatorname{RSD}^{\mathrm{a}}$ & $24 \%$ & $10 \%$ & $22 \%$ & $19 \%$ & $28 \%$ & $33 \%$ & $26 \%$ & $13 \%$ & $32 \%$ \\
\hline$N^{b}$ & 7 & 6 & 6 & 6 & 5 & 6 & 6 & 2 & 2 \\
\hline Activity & $0.41 \%$ & $0.49 \%$ & $0.055 \%$ & $0.070 \%$ & $0.017 \%$ & $0.013 \%$ & $0.015 \%$ & $0.12 \%$ & $0.044 \%$ \\
\hline \multicolumn{10}{|c|}{$30^{\circ} \mathrm{C}$} \\
\hline HS Conc. (ng/mL) & 2.438 & 1.999 & 0.230 & 0.395 & 0.085 & 0.065 & 0.058 & 0.375 & 0.224 \\
\hline $\mathrm{VP}(\mathrm{mPa})$ & 37.9 & 31.1 & 3.6 & 6.1 & 1.3 & 1.0 & 0.90 & 5.8 & 3.5 \\
\hline RSD & $2.2 \%$ & $15 \%$ & $15 \%$ & $8.8 \%$ & $9.2 \%$ & $36 \%$ & $20 \%$ & $18 \%$ & $6.4 \%$ \\
\hline $\mathrm{N}$ & 2 & 2 & 2 & 2 & 2 & 2 & 2 & 2 & 2 \\
\hline Activity & $0.77 \%$ & $0.63 \%$ & $0.073 \%$ & $0.13 \%$ & $0.027 \%$ & $0.021 \%$ & $0.018 \%$ & $0.12 \%$ & $0.071 \%$ \\
\hline \multicolumn{10}{|c|}{$39.5^{\circ} \mathrm{C}$} \\
\hline HS Conc. (ng/mL) & 5.510 & 4.818 & 0.715 & 0.883 & 0.194 & 0.160 & 0.146 & 1.45 & 0.571 \\
\hline $\mathrm{VP}(\mathrm{mPa})$ & 88.3 & 77.3 & 11.5 & 14.2 & 3.1 & 2.6 & 2.3 & 23.2 & 9.2 \\
\hline RSD & $19 \%$ & $24 \%$ & $17 \%$ & $35 \%$ & $10 \%$ & $13 \%$ & $26 \%$ & $23 \%$ & $28 \%$ \\
\hline $\mathrm{N}$ & 3 & 3 & 3 & 3 & 3 & 3 & 2 & 3 & 4 \\
\hline Activity & $0.89 \%$ & $0.78 \%$ & $0.12 \%$ & $0.14 \%$ & $0.031 \%$ & $0.026 \%$ & $0.024 \%$ & $0.23 \%$ & $0.093 \%$ \\
\hline
\end{tabular}

a $\quad \mathrm{RSD}=$ relative standard deviation,

b $\mathrm{N}=$ number of replicates 
Table 5. Results for linear regression of In(vapor pressure) versus $1 /$ temperature $\left(\mathrm{K}^{-1}\right)$ along and calculated nicotine heat of vaporization ( $\Delta$ Hvap) for different tobacco types.

\begin{tabular}{lccccccccccc}
\hline & $\mathrm{BY}$ & $\mathrm{BY}_{\mathrm{U}}$ & $\mathrm{FC}_{\mathrm{L}}$ & $\mathrm{FC}_{\mathrm{U}}$ & $\mathrm{OR}_{\mathrm{L}}$ & $\mathrm{OR}_{\mathrm{M}}$ & $\mathrm{OR}_{\mathrm{U}}$ & $3 \mathrm{R} 4 \mathrm{~F}$ & $\mathrm{BL}_{\mathrm{C}}$ \\
\hline $\mathrm{R}^{2}$ & 0.975 & 0.999 & 0.999 & 0.978 & 0.988 & 0.993 & 1.000 & 0.966 & 0.994 \\
Slope (K) & -11032 & -9408 & -11041 & -10706 & -10158 & -10517 & -9265 & -10797 & -10937 \\
Intercept & 39.8 & 34.4 & 37.7 & 37.0 & 33.7 & 34.6 & 30.5 & 37.6 & 37.2 \\
$\Delta$ Hvap (kJ/mol) & 91.7 & 78.2 & 91.8 & 89.0 & 84.5 & 87.4 & 77.0 & 89.8 & 90.9 \\
\hline
\end{tabular}

than that of pure nicotine as shown by the nicotine activity. At $23{ }^{\circ} \mathrm{C}$, the vapor pressure ranged from $0.01 \%$ to $0.5 \%$ that of pure nicotine depending on the tobacco grade. At $39.5{ }^{\circ} \mathrm{C}$ the nicotine activity was about 2 times that at $23{ }^{\circ} \mathrm{C}$.

Table 5 shows the results for the linear regression of $\ln$ (nicotine vapor pressure) versus $1 / \mathrm{T}\left(\mathrm{K}^{-1}\right)$ for the different tobacco types along with the $\Delta$ Hvap calculated from the slope. The mean values for vapor pressure shown in Table 4 were used to give equal weighting to the data for each temperature. If the individual data points were used, the $23{ }^{\circ} \mathrm{C}$ data would have been given more weight. Practically, this made little difference. For example for the Burley grades, the slope was $5 \%$ higher and $0.1 \%$ lower for the lower and upper stalk grades, respectively, if the individual data points were used. The $\mathrm{R}^{2}$ values ranged from 0.967 for the $3 \mathrm{R} 4 \mathrm{~F}$ blend to 1.000 for the upper stalk Izmir grade. The $\Delta$ Hvap ranged from $77 \mathrm{~kJ} / \mathrm{mol}$ to $91 \mathrm{~kJ} / \mathrm{mol}$ with no obvious trends with regard to tobacco origin, type or stalk position or even the wide range of nicotine activities. For example the two Burley grades, which had the highest nicotine activities, had $\Delta$ Hvap values at both the high and low ends of the range while the three Oriental grades, which had the lowest nicotine activities, spanned the whole range but not in order of stalk position or nicotine concentration. This indicates that the variation could mainly be due to experimental variability. The mean $\Delta$ Hvap for all tobacco types combined was $86.7 \mathrm{~kJ} / \mathrm{mol}$ with a standard deviation of $5.64 \mathrm{~kJ} / \mathrm{mol}$.

\section{DISCUSSION}

The measurement of the vapor pressure of nicotine proved to be more difficult than initially anticipated. Nicotine is both hydrophilic and lipophilic and the mass per sample ranged from 30-1200 ng at room temperature. This limited material selection for storage and equilibration due to both absorption into organic materials and adsorption on surfaces. Contact with appreciable amounts of polymeric organic materials resulted in lower headspace concentrations for equilibration times in the multi-week time frame. However, by using aluminum foil-lined gas bags with sampling through a PTFE lined septum, we were able to achieve vapor pressures and a heat of vaporization of nicotine that compared favorably to published values. The XAD-4 resin, which was found to be suitable for sampling environmental tobacco smoke (ETS) nicotine at the mid to upper end of this range, only gave about $62 \%$ of the recovery found with in-syringe sampling. We have no explanation for the difference. The extraction solution that we used did not have quinoline as an internal standard as did the ETS method but did have a higher concentration of triethylamine. We checked for breakthrough by using two XAD-4 cartridges in series, but found no nicotine above baseline in the second cartridge. In the end we decided to account for the difference mathematically.

This methodology was then applied for the measurement of the vapor pressure of nicotine from a range of tobacco types and corrected for XAD- 4 recovery. The nicotine vapor pressures from tobacco were $<1 \%$ of the vapor pressure of pure nicotine. This is not surprising since nicotine in tobacco exists in a protonated salt form rather than as unprotonated nicotine $(24,25)$. The $\mathrm{pH}$ of water extracts of the tobacco samples ranged from 5.0 to 6.2. Using a $\mathrm{pKa}_{1}$ of 2.90 and a $\mathrm{pKa}_{2}$ of 7.99 for nicotine at $23{ }^{\circ} \mathrm{C}(26)$, only $0.10 \%$ to $1.6 \%$ of the available nicotine was calculated to be unprotonated at pH 5.0 and 6.2, respectively. Furthermore, the tobacco samples were conditioned to a water activity of $0.61-0.62$ prior to measurement. Using the equations from NORTON et al. $(3,22)$ for the vapor pressure of water and nicotine for nicotine-water solutions at $25^{\circ} \mathrm{C}$, a water activity of 0.61 would occur with a $1.9 \%$ (w:w) nicotine in water solution (mole fractions are much different from mass fractions due to the 9 fold difference in molecular weight) and the nicotine activity would be 0.318 (i.e., $31.8 \%$ in the format used in this paper).

Figure 4 shows the relationship between the nicotine activity and the calculated percentage of unprotonated nicotine for each tobacco type. The fraction of the total nicotine in tobacco that would be unprotonated was calculated by using the measured $\mathrm{pH}$ of the tobacco extracts along with the temperature dependent $\mathrm{pKa}$ values determined by CLAYTON et al. (26). This was multiplied by the measured \% nicotine values (dry weight basis) shown in Table 2. Bear in mind that the measured $\mathrm{pH}$ is not the actual hydrogen ion activity in the tobacco as used in this experiment, but was determined using a dilute aqueous extract of the tobacco. For example, it was reported that the measured $\mathrm{pH}$ of snus extract decreases by $0.6 \mathrm{pH}$ units when changing from a $2 \%$ tobacco:water extract, typical of conventional tobacco $\mathrm{pH}$ measurement, to a $50 \%$ tobacco:water extract (27). For this calculation, the tobacco extract $\mathrm{pH}$ was being used with the understanding that it was a rough approximation of the hydrogen ion activity in tobacco as discussed more thoroughly by SEEMAN et al. (25).

The data in Figure 4 show a non-linear increase in nicotine activity as the unprotonated nicotine concentration increased and tended to unify the data in spite of the differences in tobacco types. The data from the Burley blends expand the scale for Figure 4(a) such that the data from the other blend types is obscured. Therefore, Figure 4(b) shows the lower left corner of Figure 4(a) 


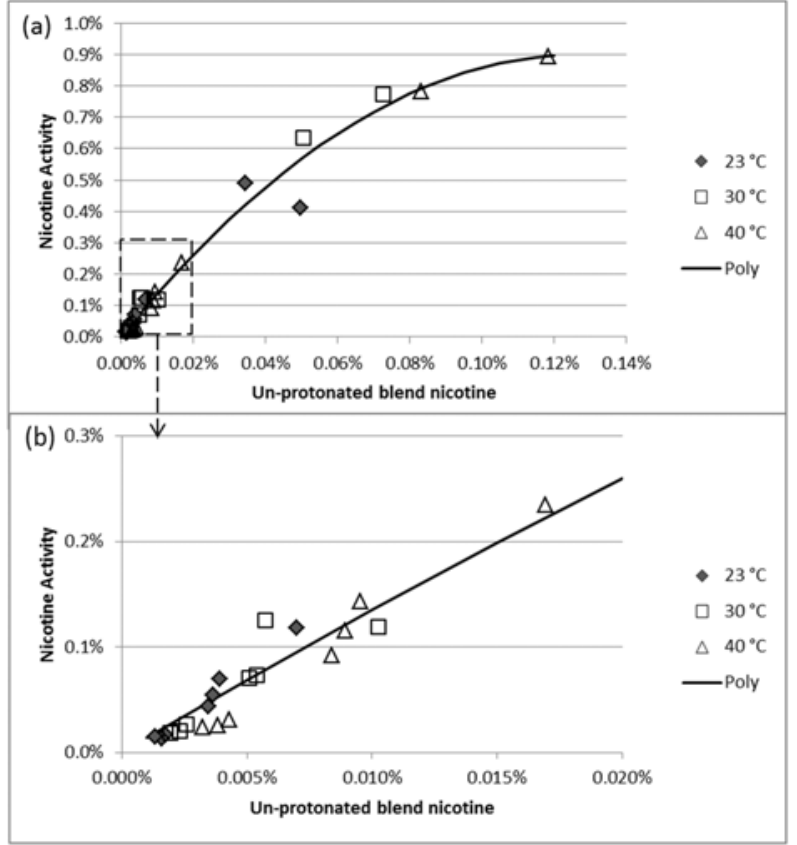

Figure 4. Measured nicotine activity versus estimated un-protonated nicotine in the tobacco including a polynomial fit to the data (Poly). (a) All data shown. (b) Expanded view of lower range.

expanded. The data were curve-fit to a simple polynomial fit, $\mathrm{Y}=\mathrm{a}+\mathrm{bX}+\mathrm{c} \mathrm{X}^{2}$ shown by the solid line. The constant term, 'a', was not statistically significant $(p=0.74)$ so the intercept was forced through zero. The resulting statistically significant coefficients $\left(p<10^{-7}\right)$ were $b=14.119$ and $\mathrm{c}=-5542$ with $\mathrm{R}^{2}=0.986$ and a standard error of $0.04 \%$ nicotine activity. Without an underlying physical model, any extrapolation outside the data ranges for this experiment would be unreliable.

The tobacco types tested differed significantly in origin, chemical makeup and nicotine concentration. This resulted in much different nicotine activity values, but the $\Delta$ Hvap values were remarkably close for these different tobacco types. The pooled value of $86.7 \mathrm{~kJ} / \mathrm{mol}$ had a coefficient of variation of $6.5 \%$ when all tobacco types were averaged. This was $53 \%$ greater than the $\Delta \mathrm{Hvap}$ of $56.6 \mathrm{~kJ} / \mathrm{mol}$ which we determined for pure nicotine. This must be due to the protonated salt form of nicotine that exists in tobacco. It is known that the reaction of nicotine with organic acids is exothermic $(25,26)$ so the reverse of this reaction would be endothermic. The nicotine salt must be dissociated to form unprotonated nicotine in order for the nicotine to vaporize (25). The $\Delta$ Hvap for nicotine from tobacco was about $30 \mathrm{~kJ} / \mathrm{mol}$ more endothermic than that found for pure nicotine. The enthalpy of protonation for the pyrrolidine ring, representing the transition from unprotonated to mono-protonated nicotine, has been reported as -33.7 , -34.3 , and $-41.3 \mathrm{~kJ} / \mathrm{mol}$ in dilute water solutions $(22,26)$, therefore it seems reasonable that the higher $\Delta$ Hvap was due to the reverse of this protonation step. This would also account for the relatively close agreement with widely varying tobacco types, since this would be an intrinsic property of the nicotine in the tobacco rather than the tobacco type. If this were the case, then it implies that the primary form of nicotine in these tobacco samples was mono-protonated rather than the di-protonated form indicated in the evolved gas analysis of Burley (25). The enthalpy of protonation for both rings (i.e., di-protonated nicotine) would be around $-60 \mathrm{~kJ} / \mathrm{mol}(26)$.

\section{CONCLUSION}

The measurement of the vapor pressure of nicotine, both neat and from tobacco, presented a number of challenges. The headspace volumes required for tobacco necessitated a flexible container, yet flexible polymers or rubber absorb and transmit nicotine. Even Tedlar ${ }^{\circledR}$ bags resulted in a slight reduction in headspace concentration. We used aluminum foil liners in an attempt to remedy this. However, the foils used were fragile and could tear and develop pinholes with use. Thicker gauges than used in this study could help in this respect for future studies. Nicotine also adsorbs on glassware and other materials used for trapping and extraction so TEA was added to the extraction solution to counteract this effect. Even with a modified extraction solution, we only had about a $62 \%$ recovery from the XAD4 resin that proved successful for nicotine in ETS. Finally, due to toxicity, the quantity of pure nicotine used in these experiments needs to be handled with extreme caution (28). In spite of the challenges, the use of aluminum foil liners allowed us to measure headspace concentrations which corresponded to previously measured values of nicotine vapor pressure. The same technique, along with a correction for XAD-4 recovery, was used for Burley, Flue-cured and Oriental grades as well as two cigarette blends at 23, 30 , and $40{ }^{\circ} \mathrm{C}$. We found that the nicotine activity (defined as vapor pressure/pure nicotine vapor pressure) from tobacco was less than $1 \%$ with Burley $>$ Flue-cured $>$ Oriental. At $23{ }^{\circ} \mathrm{C}$ the nicotine vapor pressures ranged from $0.45 \mathrm{mPa}$ for Oriental tobacco to $13 \mathrm{mPa}$ for Burley while pure nicotine was $2.95 \mathrm{~Pa}$. In general, the nicotine activity increased as the (calculated) unprotonated nicotine concentration increased. The $\Delta$ Hvap ranged from $77 \mathrm{~kJ} / \mathrm{mol}$ to $91 \mathrm{~kJ} / \mathrm{mol}$ with no obvious trends with regard to tobacco origin, type or stalk position or even the wide range of nicotine activities. The mean value for all tobacco types was $86.7 \mathrm{~kJ} / \mathrm{mol}$ with a relative standard deviation of $6.5 \%$ indicating that this was an intrinsic property of the nicotine in tobacco rather than the tobacco properties. This value was about $30 \mathrm{~kJ} / \mathrm{mol}$ greater than that of pure nicotine which is similar to the energy needed to remove a proton from mono-protonated nicotine.

\section{REFERENCES}

1. St.Charles, F.K., S.C. Moldoveanu, H.D. Mills, and N.P. Andresen: The Migration During Storage, Transfer to Smoke and Filtration Efficiency of Nicotine, Glycerin, and Propylene Glycol in Cigarettes; $67^{\text {th }}$ Tobacco Science Research Conference, Program Booklet and Abstracts, Vol. 67, Paper No. 38, 2013, pp. 38-39.

2. Harlan, W.R. and R.M. Hixon: Volatility of Nicotine; Ind. Eng. Chem. 20 (1928) 723-724.

3. Norton, L.B., C.R. Bigelow, and W.B. Vincent: Partial Vapor Pressures from Nicotine Solutions at $25^{\circ}$; J. Am. 
Chem. Soc. 62 (1940) 261-264.

4. Boldridge, D.W. and S.P. Kelly: Nicotine Vapor Pressure at Moderate Temperatures; Bates number 508791831508791838, available at https://industrydocuments. library.ucsf.edu/tobacco/docs/\#id=jnpj0100 (accessed November 20, 2015).

5. Johnson, R.R.: The Vapor Pressure Curve of Nicotine; Bates number 575102807-575102811, available at http://legacy.library.ucsf.edu/tid/fma51f00/pdf(accessed April 7, 2015).

6. Ray, A.K.: Vapor Pressure of Nicotine - A Research Report; May 29, 1990, Bates number 620503134620503137, available at https://industrydocuments. library.ucsf.edu/tobacco/docs/\#id=xzll0141 (accessed November 20, 2015).

7. National Institutes of Health, U.S. National Library of Medicine, National Center for Biotechnology Information: PubChem Open Chemistry Database; available at https://pubchem.ncbi.nlm.nih.gov/compound/1030\# section=Vapor-Pressure (accessed January 15, 2016).

8. Cammenga, H.K., F.W. Schulze, and W. Theuerl: Vapor Pressure and Evaporation Coefficient of Glycerol; J. Chem. Eng. Data 22 (1977) 131-134.

9. Rix, C.E., R.A. Lloyd, and C.W. Miller: Headspace Analysis of Tobacco with Tenax Traps; Tob. Sci. 21 (1977) 93-96.

10. Sakaki, T., K. Niino, H. Sakuma, and S. Sugawara: Analysis of Tobacco Headspace Volatiles Using Tenax GC or Active Carbon; Agric. Biol. Chem. 48 (1984) 3121-3128

11. Merckel, C., F. Pragst, A. Ratzinger, B. Aebi, W. Bernhard, and F. Sporkert: Application of Headspace Solid Phase Microextraction to Qualitative and Quantitative Analysis of Tobacco Additives in Cigarettes; J. Chromatogr. A 1116 (2006) 10-19.

12. Site, A.D.: The Vapor Pressure of Environmentally Significant Organic Chemicals: A Review of Methods and Data at Ambient Temperature; J. Phys. Chem. Ref. Data 26 (1997) 157-193.

13. Chickos, J.S.: A Simple Equilibrium Method for Determining Heats of Sublimation; J. Chem. Educ. 52 (1975) 134-136.

14. Ogden, M.W.: Gas Chromatographic Determination of Nicotine in Environmental Tobacco Smoke: Collaborative Study; J. Assoc. Off. Anal. Chem. 72 (1989) 1002-1006.

15. Ogden, M.W.: Equivalency of Gas Chromatographic Conditions in Determination of Nicotine in Environmental Tobacco Smoke: Minicollaborative Study; J. Assoc. Off. Anal. Chem. Int. 75 (1992) 729-733.

16. American Society for Testing and Materials (ASTM) International: ASTM D5075-01(2012)e1-Standard Test Method for Nicotine and 3-Ethenylpyridine in Indoor Air; ASTM International, West Conshohocken, PA, USA, 2012.

17. Cooperation Centre for Scientific Research Relative to Tobacco (CORESTA): CORESTA Recommended method No. 50. Environmental Tobacco Smoke - Determination of Nicotine and 3-Ethenylpyridine in the Vapour Phase; CORESTA, Paris, 2012, available at http://www.coresta.org/Recommended_Methods/ CRMs.htm (accessed November 20, 2015).
18. Grubner, O., M.W. First, and G.L. Huber: Gas Chromatographic Determination of Nicotine in Gases and Liquids with Suppression of Adsorption Effects; Anal. Chem. 52 (1980) 1755-1758.

19. Ogden, M.W., L.W. Eudy, D.L. Heavner, F.W. Conrad Jr, and C.R. Green: Improved Gas Chromatographic Determination of Nicotine in Environmental Tobacco Smoke; Analyst 114 (1989) 1005-1008.

20. United States of America, Department of Health and Human Services: Notice Regarding Revisions to the Laboratory Protocol To Measure the Quantity of Nicotine Contained in Smokeless Tobacco Products Manufactured, Imported, or Packaged in the United States; Federal Register, Vol. 74, No. 4, January 7, 2009, 715-716.

21. Walker, J.C., D.B. Kurtz, F.M. Shore, M.W. Ogden, and J.H. Reynolds IV: Apparatus for the Automated Measurement of the Responses of Humans to Odorants; Chem. Senses 15 (1990) 165-177.

22. Banyasz, J.L.: The Physical Chemistry of Nicotine; in: Analytical Determination of Nicotine and Related Compounds and Their Metabolites, edited by J.W. Gorrod and P. Jacob III, Elsevier Science B.V., Amsterdam, The Netherlands, 1999, pp. 149-190.

23. Mohr, P.J., B.N. Taylor, and D.B. Newell: CODATA Recommended Values of the Fundamental Physical Constants 2010; Rev. Mod. Phys. 84 (2012) 1527-1605.

24. Perfetti, T.A., A.B. Norman, B.M. Gordon, W.M. Coleman III, W.T. Morgan, G.M. Dull, and C.W. Miller: The Transfer of Nicotine From Nicotine Salts to Mainstream Smoke; Beitr. Tabakforsch. Int. 19 (2000) 141-158.

25. Seeman, J.I., J.A. Fournier, J.B. Paine III, and B.E. Waymack: The Form of Nicotine in Tobacco. Thermal Transfer of Nicotine and Nicotine Acid Salts to Nicotine in the Gas Phase; J. Agric. Food Chem. 47 (1999) 5133-5145.

26. Clayton, P.M., C.A. Vas, T.T.T. Bui, A.F. Drake, and K. McAdam: Spectroscopic Investigations into the AcidBase Properties of Nicotine at Different Temperatures; Anal. Methods 5 (2013) 81-88.

27. McAdam, K., L. Bishop, H. Digard, C. Liu, and J. Tetteh: Analysis of Free-Base Nicotine and Volatile Ingredients in Smokeless Tobacco by Headspace-SPME GC/MS; Poster presented at the Joint Conference of SRNT and SRNT-Europe, April 27-30, 2009, Dublin, Ireland, available at http://www.bat-science.com/ groupms/sites/BAT_9GVJXS.nsf/vwPagesWebLive/D O83EF6Q/\$FILE/Free\%20based\%20nicotine SRNT 2 009.pdf?openelement (accessed November 20, 2015).

28. Mayer, B.: How Much Nicotine Kills a Human? Tracing Back the Generally Accepted Lethal Dose to Dubious Self-Experiments in the Nineteenth Century; Arch. Toxicol. 88 (2014) 5-7.

Corresponding author:

Serban C. Moldoveanu

R.J. Reynolds Tobacco Co.

950 Reynolds Boulevard

Winston-Salem, NC 27105, USA

E-mail:MoldovS@RJRT.com 